\title{
Papillary Pattern
}

National Cancer Institute

\section{Source}

National Cancer Institute. Papillary Pattern. NCI Thesaurus. Code C35911.

A morphologic finding indicating the presence of a cellular infiltrate with papillary growth in a tissue sample. 